CZASOPISMO INŻYNIERII LA¿OWEJ, ŚRODOWISKA I ARCHITEKTURY JOURNAL OF CIVIL ENGINEERING, ENVIRONMENT AND ARCHITECTURE

JCEEA, t. XXXIII, z. 63 (4/16), październik-grudzień 2016, s. 443-450

Patrycja PRAŻMO ${ }^{1}$

Miłosz SZEWCZYK ${ }^{2}$

Sławomir GUŁKOWSKI ${ }^{3}$

\title{
POMIAR CHARAKTERYSTYKI PRĄDOWO- NAPIECIOWEJ OGNIWA FOTOWOLTAICZNEGO METODĄ POJEMNOŚCIOWĄ W WARUNKACH OŚWIETLENIA SZTUCZNEGO
}

\begin{abstract}
Charakterystyka prądowo-napięciowa to podstawowa forma prezentacji parametrów elektrycznych ogniwa fotowoltaicznego. Wykres krzywej I-V modułu PV zmienia się w ciągu dnia w zależności od natężenia promieniowania słonecznego oraz temperatury modułu.

Artykuł przedstawia pomiary krzywych I-V w warunkach oświetlenia sztucznego wykonanych autorskim urządzeniem. W skład układu pomiarowego oprócz urządzenia wchodził również komputer sterujący wraz z oprogramowaniem Arduino w celu kontroli procesu pomiaru oraz zapisu odczytu danych do pliku. Spośród różnych dostępnych metod pomiarowych do realizacji urządzenia wybrano metodę pojemnościową wykorzystującą proces ładowania kondensatora do zmiany rezystancji układu od zera do nieskończoności. Taka metoda pomiaru nie umożliwia odtworzenia krzywej od punktu zwarcia i wymaga ekstrapolacji wyników, natomiast wykorzystuje ona stosunkowo łatwy w konstrukcji układ elektroniczny a także nie jest ona kosztowna. Urządzenie mierzy napięcie poprzez wbudowany konwerter ADC porównując badane napięcie $\mathrm{z}$ napięciem referencyjnym oraz natężenie prądu $\mathrm{w}$ obwodzie wykorzystując czujnik natężenia oparty o efekt Halla. W pracy porównano rezultaty pomiarów dla dwóch różnych typów ogniw fotowoltaicznych: polikrystalicznego i monokrystalicznego ogniwa krzemowego. Otrzymane wyniki zaprezentowano w formie wykresów. Porównano na nich wyniki dla kilku pomiarów oraz wartości uśrednionych. Porównano obliczone wartości współczynnika wypełnienia, który określa stosunek mocy maksymalnej ogniwa rzeczywistego do mocy maksymalnej ogniwa idealnego $\mathrm{z}$ danymi podanymi przez producenta.
\end{abstract}

Słowa kluczowe: krzywa I-V, moduł fotowoltaiczny, metoda kondensatorowa, warunki wewnętrzne

${ }^{1}$ Autor do korespondencji / corresponding author: Patrycja Prażmo, Politechnika Lubelska, Instytut Odnawialnych Źródeł Energii, ul. Nadbystrzycka 38, 20-618 Lublin; tel. 793051585; pprazmo.lub@gmail.com

2 Miłosz Szewczyk, Politechnika Lubelska, Instytut Odnawialnych Źródeł Energii, ul. Nadbystrzycka 38, 20-618 Lublin; milosz.szewczyk@gmail.com

${ }^{3}$ Sławomir Gułkowski, Politechnika Lubelska, Instytut Odnawialnych Źródeł Energii, ul. Nadbystrzycka 38, 20-618 Lublin; tel 81538 46 54, s.gulkowski@ pollub.pl 


\section{Wprowadzenie}

Jednym z największych wyzwań przemysłu energetyki słonecznej jest redukcja kosztu produkcji energii z generatorów PV. Najistotniejszym czynnikiem wpływającym na całkowity koszt oraz żywotność instalacji jest sprawność modułów fotowoltaicznych a także czas degradacji ich mocy. Aby sprawdzić wydajność modułu oraz oszacować jej zmianę w czasie należy dokonać pomiaru charakterystyki prądowo napięciowej.

\subsection{Charakterystyka prądowo-napięciowa}

Sprawność modułu PV definiujemy jako moc generowaną przez ogniwo $\left(\mathrm{P}_{\mathrm{m}}\right)$ podzieloną przez iloczyn natężenia oświetlenia oraz pola powierzchni czynnej modułu [1].

$$
\eta=\frac{\mathrm{P}_{\mathrm{m}}}{\operatorname{Irr} * \mathrm{~S}} * 100 \%
$$

gdzie: $\mathrm{P}_{\mathrm{m}}$ - punkt mocy maksymalnej (MPP - ang. Maximum Power Point) [W], Irr - natężenie promieniowania $\left[\mathrm{W} / \mathrm{m}^{2}\right]$,

$\mathrm{S}$ - pole powierzchni czynnej modułu $\left[\mathrm{m}^{2}\right]$.

Moc maksymalną ogniwa rzeczywistego $\left(\mathrm{P}_{\mathrm{m}}\right)$ możemy obliczyć ze wzoru:

$$
\mathrm{P}_{\mathrm{m}}=\mathrm{I}_{\mathrm{m}} \mathrm{U}_{\mathrm{m}}
$$

gdzie : $I_{m}, U_{m}$, prąd oraz napięcie w punkcie mocy maksymalnej [1].

Natężenie maksymalne $\mathrm{I}_{\mathrm{m}}$ oraz napięcie maksymalne $\mathrm{U}_{\mathrm{m}}$ są wartościami dla których w danej chwili moc generowana przez ogniwo jest maksymalna. Wraz ze wzrostem temperatury parametry charakterystyki I-V ulegają zmianie. Rośnie prąd zwarciowy i maleje napięcie obwodu otwartego, a więc maleje moc maksymalna. Wartość wytwarzanej mocy zależy proporcjonalnie od natężenia promieniowania co wykazuje wzór (1).

Wyznaczenie punktu mocy maksymalnej jest kluczowe dla wyznaczenia współczynnika wypełnienia FF (ang. Fill Factor) obliczany ze wzoru [2]:

$$
\mathrm{FF}=\frac{\mathrm{I}_{\mathrm{m}} \mathrm{U}_{\mathrm{m}}}{\mathrm{I}_{\mathrm{SC}} \mathrm{U}_{\mathrm{OC}}}
$$

Określa on stosunek mocy maksymalnej ogniwa rzeczywistego do mocy maksymalnej ogniwa idealnego,

gdzie: Isc - prąd zwarcia [A],

Uoc - napięcie obwodu otwartego [V] [2]. 
Na podstawie wzoru (1) i (3) możemy wyprowadzić zależność:

$$
\eta=\frac{\mathrm{FF} * \mathrm{I}_{\mathrm{SC}} * \mathrm{U}_{\mathrm{OC}}}{\mathrm{I}_{\mathrm{rr}} * \mathrm{~S}} * 100 \%
$$

gdzie: FF - współczynnik wypełnienia,

Isc - prąd zwarcia [A],

Uoc - napięcie obwodu otwartego [V],

Irr - natężenie promieniowania padającego na ogniwo $\left[\mathrm{W} / \mathrm{m}^{2}\right]$,

$\mathrm{S}$ - pole powierzchni czynnej modułu $\left[\mathrm{m}^{2}\right]$.

Powyższe parametry pracy modułu odczytywane są z wykresu charakterystyki prądowo-napięciowej. Dla ogniwa idealnego ma ona kształt prostokątny o bokach $\mathrm{I}_{\mathrm{sc}}$ (prądu zwarcia) oraz $\mathrm{U}_{\text {oc }}$ (napięcia obwodu otwartego), natomiast dla ogniwa rzeczywistego przyjmuje kształt krzywej przechodzącej przez punkty $\mathrm{I}_{\mathrm{sc}}, \mathrm{U}_{\mathrm{oc}}$ oraz MPP.

\subsection{Metody pomiaru charakterystyk I-V}

Najprostszą metodą wykreślania krzywej prądowo-napięciowej jest metoda zmiennego oporu, w której punkty charakterystyki od obwodu otwartego do odwodu zwartego otrzymuje się poprzez stopniową zmianę wartości oporu od zera do nieskończoności [3]. Metoda ta sprawdza się tylko w przypadku modułów o niskiej mocy. Nie umożliwia ona osiągnięcia punktu zwarcia. Metoda ta jest niedokładna ze względu na zmieniające się warunki atmosferyczne oraz ze względu na fakt, iż wzrasta temperatura modułu.

Innymi znanymi metodami pomiaru są [4]:

- Metoda pojemnościowa;

- Metoda z użyciem zasilacza czterokwadrantowego;

- Metoda z użyciem konwertera DC-DC;

- Metoda tranzystorowa.

Metody te różnią się w zakresie wielu parametrów takich jak elastyczność metody, modularność, dokładność, szybkość oraz koszt urządzenia co porównano w tabeli 1 .

Tabela 1. Porównanie metod pomiaru charakterystyki I-V

Table 1. Comparison of methods the I-V measurement

\begin{tabular}{|c|c|c|c|c|c|}
\hline Metoda pomiaru & Elastyczność & Modułowość & Dokładność & $\begin{array}{c}\text { Szybkość } \\
\text { reakcji }\end{array}$ & Koszt \\
\hline Metoda pojemnościowa & niska & średnia & średnia & niska & niski \\
\hline $\begin{array}{c}\text { Czterokwadrantowy } \\
\text { zasilacz mocy }\end{array}$ & wysoka & wysoka & wysoka & wysoka & wysoki \\
\hline Konwerter DC-DC & średnia & wysoka & wysoka & wysoka & niski \\
\hline Metoda tranzystorowa & wysoka & niska & średnia & średnia & średni \\
\hline
\end{tabular}


Metoda pojemnościowa została wybrana przy konstrukcji urządzenia pomiarowego ze względu na niski koszt oraz stosunkowo prostą konstrukcję układu elektronicznego.

\section{Opis procedury badawczej}

Układ pomiarowy przedstawiony na rys 1 . składał się ze źródła światła (lampy halogenowej o mocy $1000 \mathrm{~W}$ ), badanego modułu fotowoltaicznego (polikrystalicznego o mocy $10 \mathrm{~W}$ oraz monokrystalicznego o mocy $13 \mathrm{~W}$ ), autorskiego urządzenia pomiarowego bazującego na metodzie pojemnościowej pomiaru charakterystyki I-V modułu, komputera oraz dodatkowego miernika napięcia.

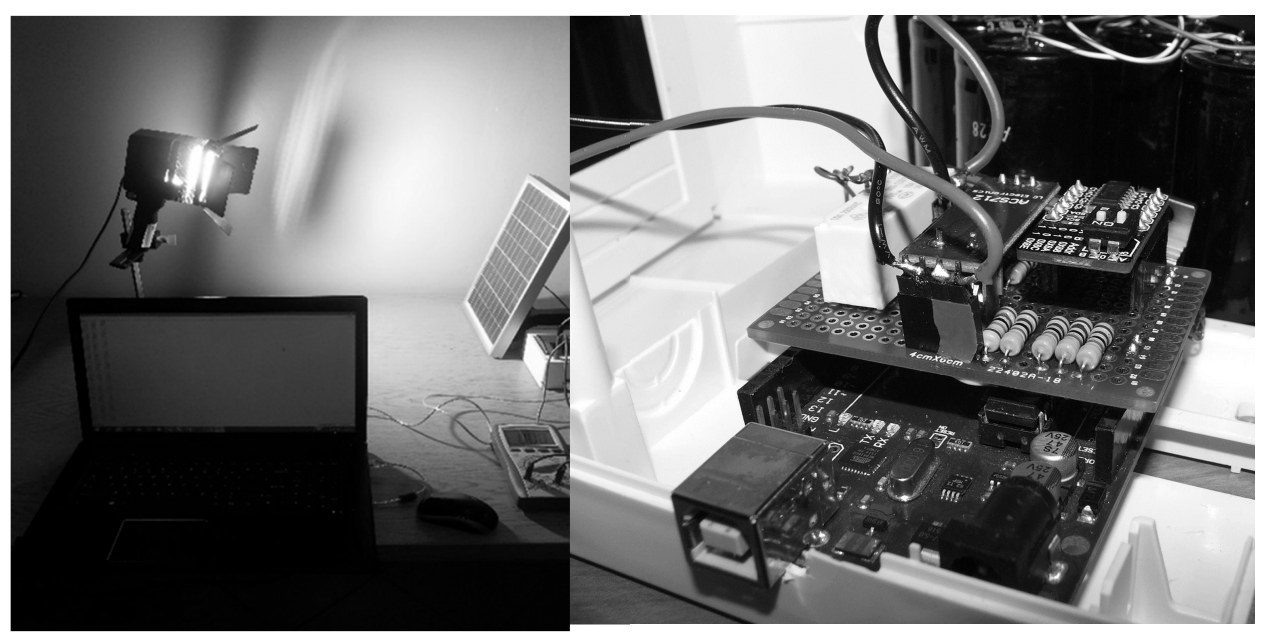

Rys. 1. Układ pomiarowy do badania charakterystyki I-V modułu polikrystalicznego o mocy $10 \mathrm{~W}$

Fig. 1. The measuring circuit for testing the I-V characteristics of the $10 \mathrm{~W}$ polycrystalline module
Rys. 2. Autorskie urządzenie pomiarowe do badania charakterystyki I-V

Fig. 2. Self-made measuring device for testing the I-V characteristics

W autorskim urządzeniu pomiarowym przedstawionym na rysunku 2 wykorzystano kondensatory elektrolityczne. Ponieważ kondensatorów tego typu nie można naładować ujemnie urządzenie nie generowało początkowego fragmentu krzywej I-V (punktów przy I $\mathrm{I}_{\mathrm{sc}}$ ).

Rysunek 3 przedstawia schemat pracy układu pomiarowego. W trakcie pomiarów od obwodu zwartego do obwodu otwartego następuje ładowanie kondensatora. Gdy napięcie wzrasta a natężenie maleje aż do zera obwód osiąga punkt obwodu otwartego. Po dokonaniu pomiaru kondensator rozładowywany jest przez rezystory. Pomiar napięcia dokonywany jest poprzez wbudowany konwerter analogowo-cyfrowy, który porównuje badane napięcie z napięciem 
referencyjnym a następnie podaje dyskretną wartość (zależną od rozdzielczości konwersji bitowej). Pomiar natężenia prądu realizowany jest poprzez zbadanie efektu Halla czujnikiem natężenia ASC712 tj. poprzez określenie napięcia Halla powstającego ze względu na działanie siły Lorentza.

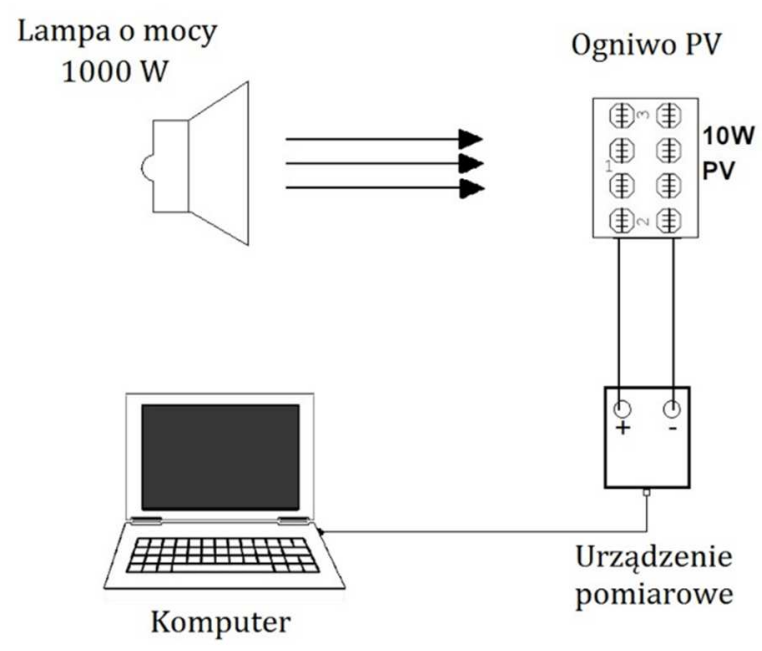

Rys. 3. Schemat układu pomiarowego

Fig. 3. Diagram of the measuring circuit

\section{Wyniki badań i ich analiza}

Rezultaty pomiarów dla krzemowego ogniwa polikrystalicznego o mocy 10W zostały przedstawione za pomocą wykresów na rys. 4 i rys. 5 . Rysunek 4 przedstawia charakterystykę prądowo-napięciową utworzoną z kolejno uśrednionych dwóch sąsiednich, odczytanych przez urządzenie punktów oraz okresowo średnią linię trendu. Na rysunku 5 została zaprezentowana uśredniona charakterystyka wykonana z trzech różnych pomiarów. Na rysunku 6 i 7 zaprezentowano charakterystykę prądowo-napięciową ogniwa monokrystalicznego o mocy $13 \mathrm{~W}$. Na wykresie z rys. 7 nie zastosowano uśredniania kolejnych punktów pomiarowych. Rysunek 8 przedstawia, analogicznie jak rysunek 5, średnią trzech różnych pomiarów dla ogniwa monokrystalicznego. Otrzymane wykresy prezentują poprawny kształt krzywej I-V. Na wykresach widoczne są fluktuacje zwłaszcza z zakresie pomiaru natężenia. Wahania te zmniejszają się na wykresach uśrednionych charakterystyk dla różnych pomiarów (Rys.5, Rys.7). 


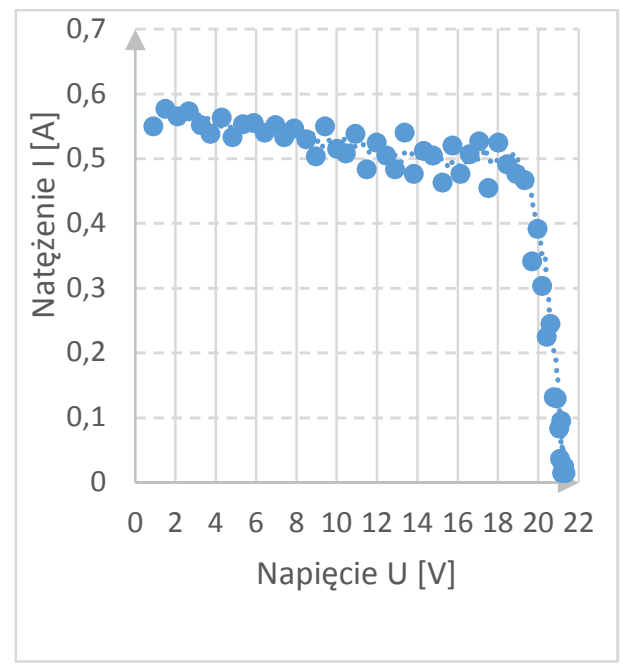

Rys. 4. Charakterystyka prądowo-napięciowa ogniwa polikrystalicznego o mocy 10W

Fig. 4. I-V characteristics of $10 \mathrm{~W}$ PV module

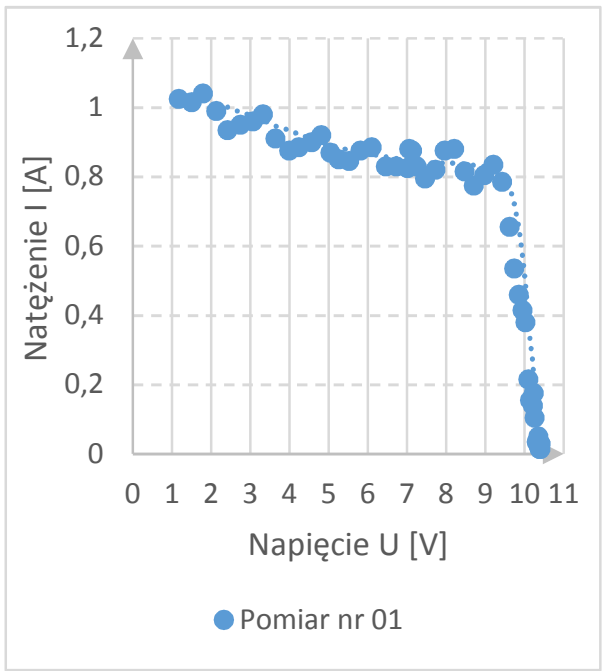

Rys. 6. Charakterystyka prądowo-napięciowa ogniwa monokrystalicznego o mocy $13 \mathrm{~W}$ Fig. 6. I-V characteristics of $13 \mathrm{~W}$ PV module

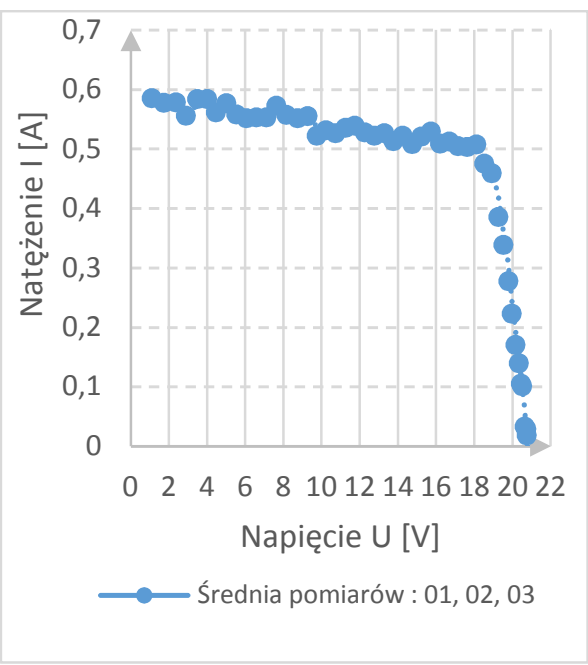

Rys. 5. Charakterystyka prądowo napięciowa po uśrednieniu trzech kolejnych pomiarów dla ogniwa polikrystalicznego o mocy $10 \mathrm{~W}$

Fig. 5. The average characteristics of the three measurements for 10W PV module

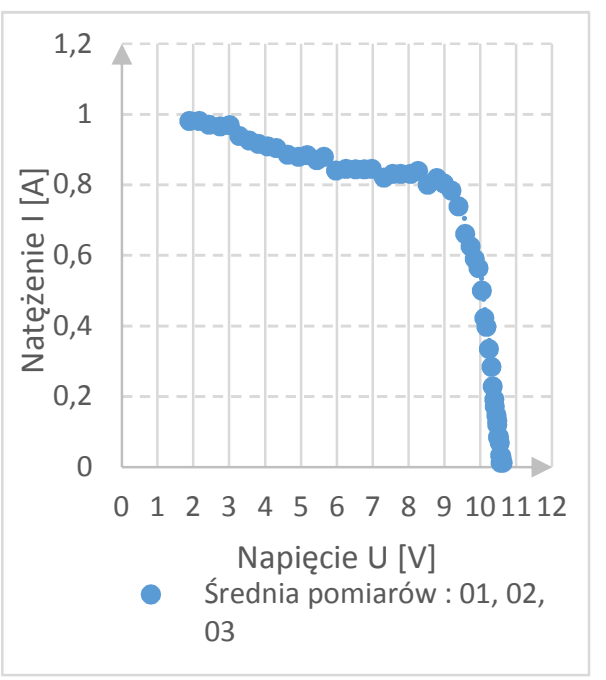

Rys. 7. Charakterystyka prądowo napięciowa po uśrednieniu trzech kolejnych pomiarów dla ogniwa monokrystalicznego o mocy $13 \mathrm{~W}$

Fig. 7. The average characteristics of the three measurements for $13 \mathrm{~W}$ PV module 
Na podstawie otrzymanych wyników obliczono współczynnik wypełnienia FF - wzór (2) dla obu ogniw co przedstawiono w tabeli (Tabela 2).

Tabela 2. Porównanie wyników pomiarów z danymi producenta

Table 2. Comparison of the results of measurement with data from the manufacturer

\begin{tabular}{|c|c|c|c|c|}
\hline Wartość & $\begin{array}{c}\text { Ogniwo poli- } \\
\text { krystaliczne - } \\
\text { dane od produ- } \\
\text { centa }\end{array}$ & $\begin{array}{c}\text { Ogniwo poli- } \\
\text { krystaliczne - } \\
\text { otrzymane } \\
\text { wyniki }\end{array}$ & $\begin{array}{c}\text { Ogniwo mono- } \\
\text { krystaliczne - } \\
\text { dane od produ- } \\
\text { centa }\end{array}$ & $\begin{array}{c}\text { Ogniwo mono- } \\
\text { krystaliczne- } \\
\text { otrzymane wyniki }\end{array}$ \\
\hline $\mathrm{P}_{\mathrm{m}}$ & $10 \mathrm{~W}$ & $9,35 \mathrm{~W}$ & $13 \mathrm{~W}$ & $8.41 \mathrm{~W}$ \\
\hline $\mathrm{I}_{\mathrm{sc}}$ & $0.68 \mathrm{~A}$ & $0.637 \mathrm{~A}$ & $1.6 \mathrm{~A}$ & $1.06 \mathrm{~A}$ \\
\hline $\mathrm{U}_{\mathrm{oc}}$ & $21.0 \mathrm{~V}$ & $21.07 \mathrm{~V}$ & $10.8 \mathrm{~V}$ & $11.03 \mathrm{~V}$ \\
\hline $\mathrm{I}_{\mathrm{m}}$ & $0.6 \mathrm{~A}$ & $0.512 \mathrm{~A}$ & $1.44 \mathrm{~A}$ & $0.86 \mathrm{~A}$ \\
\hline $\mathrm{U}_{\mathrm{m}}$ & $16.8 \mathrm{~V}$ & $18.27 \mathrm{~V}$ & $9.0 \mathrm{~V}$ & $9.78 \mathrm{~V}$ \\
\hline $\mathrm{FF}$ & 0.706 & 0.697 & 0.750 & 0,719 \\
\hline
\end{tabular}

Uzyskane wyniki zostały porównane z danymi z tablic znamionowych producenta. Parametry Im, Um, Isc, Uoc różnią się od danych katalogowych. Przedstawione w tabeli 2 obliczone współczynniki FF odbiegają od podanych przez producenta. Różnica ta jest większa dla ogniwa krzemowego monokrystalicznego. Jest to spowodowane przede wszystkim warunkami pomiarów które nie były prowadzone w warunkach standardowych (STC ang. Standard Testing Conditions). Natężenie oświetlenia otrzymane z lampy jest niższe niż $1000 \mathrm{~W} / \mathrm{m}^{2}$. Urządzenie zmierzyło dużo niższe natężenia prądów (zwłaszcza w przypadku ogniwa monokrystalicznego) niż te które znajdowały się na tablicach znamionowych badanych modułów. Jednocześnie dla ogniwa monokrystalicznego różniły się one w większym stopniu niż dla ogniwa polikrystalicznego, przy czym pomiar dla ogniwa monokrystalicznego był stabilniejszy.

\section{Wnioski}

Zmierzono charakterystyki prądowo-napięciowe krzemowego polikrystalicznego i monokrystalicznego modułu fotowoltaicznego za pomocą autorskiego urządzenia pomiarowego. Odczytano wartości prądu zwarcia, napięcia obwodu otwartego oraz wartości natężenia i napięcia maksymalnego.

Obliczono wartość współczynników FF a rezultaty porównano z wartościami podanymi przez producenta. Wywnioskowano, iż wartości te różnią się, zwłaszcza w zakresie zmierzonego natężenia prądu, a wyniki są mniej dokładne zwłaszcza dla ogniwa monokrystalicznego.

Na tej podstawie można przypuszczać, że:

- Należy konfigurować oprogramowanie urządzenia dla różnych typów ogniw w zależności od wysokości generowanych przez nie prądów.

- Pomiary charakterystyk ogniw niewielkiej mocy obarczone są relatywnie dużą niepewnością pomiarową. W celu pomiaru krzywych I-V modułów małej mo- 
cy należałoby zmodyfikować urządzenie poprzez wymianę układu kondensatorów na jeden kondensator o większej pojemności, a także dobrać dzielniki napięcia oraz czujnik Halla w taki sposób, by wyniki maksymalnych pomiarów były zbliżone do napięcia referencyjnego czujników co pozwoliłoby na znacznie dokładniejszy odczyt danych.

- Urządzenie można stosować do pomiaru modułów o większej mocy z większą dokładnością pomiaru.

\section{Literatura}

[1] Chwiediuk D.: Energetyka słoneczna budynku. Arkady, Warszawa 2011.

[2] Lorenzo E.: Solar Electricity. Engineering of Photovoltaic systems. Progensa, 1994.

[3] Nelson J.: The Physics of Solar Cells. Imperial College Press, 2003.

[4] Durán E.: Different methods to obtain the I-V curve of PV modules: a review. IEEE, 2008.

[5] Krawczak E., Gułkowski S., Olchowik J.M.: Badanie efektywności pracy fotowoltaicznego systemu ,off-grid” w warunkach zimowo-wiosennych dla Lubelszczyzny, Czasopismo Inżynierii Lądowej, Środowiska i Architektury - Journal of Civil Engineering, Environment and Architecture, JCEEA, t. XXXI, z. 61 (3/II/14), 2014, s. 317-328, DOI:10.7862/rb.2014.98.

\section{I-V CHARACTERISTIC MEASUREMENT OF PV MODULES USING THE CAPACITIVE LOAD METHOD IN INDOOR CONDITIONS}

\section{S u m m a r y}

Current and voltage characteristics is the basic form of presentation of the electrical parameters of the photovoltaic cell. Chart I-V curve of the module varies throughout the day depends on the intensity of solar radiation and temperature of module.

The article presents measurements of I-V curves under artificial lighting made by selfdesigned device. The measurement system also included the control computer with Arduino software to control the process of measuring and recording the read data to the file. Among the various measuring methods was chosen a capacitive load method, which uses charging the capacitor to change the resistance from zero to infinity. This method of measurement cannot restore the curve from the short-circuit current point and requires extrapolation. The device measures the voltage via the integrated $\mathrm{ADC}$ when comparing measured voltage with a reference voltage and current in the circuit using the intensity sensor based on the Hall effect. The study compares the results of measurements for two different types of photovoltaic cells: polycrystalline and monocrystalline silicon cell. The results are presented in graphs and compared to the results of several measurements and average values.

Keywords: I-V curve, photovoltaic module, capacitive method, indoor conditions

DOI:10.7862/rb.2016.288

Przestano do redakcji: 30.06 .2016 r.

Przyjęto do druku: 20.12.2016 r. 